K. Nakajou $\cdot$ S. Horiuchi $\cdot$ M. Sakai $\cdot$ N. Haraguchi $\cdot$

M. Tanaka $\cdot$ M. Takeya $\cdot$ M. Otagiri

\title{
Renal clearance of glycolaldehyde- and methylglyoxal-modified proteins in mice is mediated by mesangial cells through a class A scavenger receptor (SR-A)
}

Received: 11 June 2004 / Accepted: 22 October 2004 / Published online: 15 January 2005

C) Springer-Verlag 2005

\begin{abstract}
Aims/hypothesis: Glomerular mesangial expansion is a characteristic feature of diabetic nephropathy, and the accumulation of AGE in the mesangial lesion has been implicated as one of its potential causes. However, the route for the AGE accumulation in mesangial lesions in diabetic patients is poorly established. Methods: Glycolaldehyde-modified BSA (GA-BSA) and methylglyoxalmodified BSA (MG-BSA) were prepared as model AGE proteins, and their in vivo plasma clearance was examined in mice, and renal uptake by in vitro studies with isolated renal mesangial cells. Results: Both ${ }^{111}$ In-GA-BSA and ${ }^{111}$ In-MG-BSA were rapidly cleared from the circulation mainly by both the liver and kidney. Immunohistochemical studies with an anti-GA-BSA antibody demonstrated that intravenously injected GA-BSA accumulated in mesangial cells, suggesting that such cells play an important role in the renal clearance of circulating AGE proteins. Binding experiments at $4^{\circ} \mathrm{C}$ using mesangial cells isolated from mice showed that ${ }^{125} \mathrm{I}-\mathrm{GA}-\mathrm{BSA}$ and ${ }^{125} \mathrm{I}-\mathrm{MG}-\mathrm{BSA}$ exhibited specific and saturable binding. Upon incubation at $37^{\circ} \mathrm{C},{ }^{125} \mathrm{I}-\mathrm{GA}-\mathrm{BSA}$ and ${ }^{125} \mathrm{I}-\mathrm{MG}-\mathrm{BSA}$ underwent endocytic degradation by these cells. The binding of the ligands to these cells was inhibited by several ligands for scavenger
\end{abstract}

K. Nakajou · N. Haraguchi · M. Otagiri

Department of Biopharmaceutics, Graduate School of

Pharmaceutical Sciences, Kumamoto University,

Kumamoto, Japan

S. Horiuchi $(\bowtie) \cdot$ M. Sakai

Department of Medical Biochemistry, Graduate School of

Medical Sciences, Kumamoto University,

1-1-1 Honjo,

Kumamoto, 860-0811, Japan

e-mail: horiuchi@gpo.kumamoto-u.ac.jp

Tel.: +81-96-3735070

Fax: +81-96-3646940

M. Tanaka $\cdot$ M. Takeya

Department of Cell Pathology, Graduate School of Medical

Sciences, Kumamoto University,

Kumamoto, Japan receptors. The endocytic degradation of GA-BSA by mesangial cells from class A scavenger receptor (SR-A) knock-out mice was reduced by $80 \%$ when compared with that of wild-type cells. The glomerular accumulation of GA-BSA after its intravenous administration was attenuated in SR-A knock-out mice, as evidenced by immunohistochemical observations. Conclusions/interpretation: These results raise the possibility that circulating AGE-modified proteins are subjected to renal clearance by mesangial cells, mainly via SR-A. This pathway may contribute to the pathogenesis of AGE-induced diabetic nephropathy.

Keywords AGE - Biological fate - Diabetic nephropathy · Endocytosis $\cdot$ Intermediate aldehydes $\cdot$ Scavenger receptor

Abbreviations Ac-LDL: Acetylated LDL - GA: Glycolaldehyde $\cdot$ MG: Methylglyoxal - Ox-LDL: Oxidized LDL $\cdot$ SR-A: Class A scavenger receptor

\section{Introduction}

The long-term incubation of proteins with glucose leads, through the formation of early products such as Schiff bases and Amadori products, finally to AGE. AGE proteins are characterised physicochemically by their fluorescent, brown color and intramolecular and intermolecular crosslinking [1], and biologically by their recognition by specific AGE receptors [2]. Recent studies reported that several aldehydes such as glycolaldehyde (GA), glyoxal, methylglyoxal (MG), and 3-deoxyglucosone are generated during the Maillard reaction from glucose, a Schiff base, or Amadori products $[3,4]$. A much stronger chemical reactivity than that of glucose indicates the important role of these aldehydes in the in vivo generation of AGE structures [5-7].

Previous studies have provided several lines of evidence for the pathological role of AGE in diabetic nephropathy. First, immunological studies using an anti-AGE antibody demonstrated the accumulation of AGE in glomerular mesangial lesions of diabetic nephropathy $[8,9]$. Second, AGE proteins prepared by the modification of BSA with ribose, 
induced TGF- $\beta$ synthesis at an mRNA level in rat mesangial cells [10]. Third, AGE proteins prepared by incubating BSA with glucose-6-phosphate increased the levels of growth factors such as TGF- $\beta$ and IGF-I and extracellular matrix proteins such as fibronectin, laminin and type IV collagen at the protein level in rat mesangial cells [11, 12]. Fourth, AGE proteins prepared by incubating BSA with glucose-6-phosphate also increased type IV collagen expression in human mesangial cells [13]. Finally, AGE proteins prepared by incubating BSA with glucose, glyceraldehyde, or GA induced the production of vascular endothelial growth factor and monocyte chemoattractant protein-1 in human mesangial cells [14].

These cellular responses to AGE proteins are believed to be mediated by AGE receptors which include the receptor for AGE (RAGE) [15], oligosaccharyltransferase-48 (OST48), 80K-H, galectin-3 complex [16], and scavenger receptors such as the class A scavenger receptor (SR-A) [17], CD36 [18], SR-BI [19], and LOX-1 [20]. Several AGE receptor(s) in mesangial cells were characterised from the potential link to diabetic nephropathy [21-23]. However, one important issue that remains unknown concerns the access of AGE ligands to these AGE receptors in the mesangial area. More specifically, it is important to determine whether AGE proteins that accumulate in the mesangium are produced at the same site, or are produced in other places and then delivered to the mesangial area. We hypothesised that the increased levels of plasma AGE proteins in the diabetic states are subjected to renal clearance by an active cellular process(es) which may lead to the subsequent accumulation of AGE proteins in the mesangial area and induction of biological responses by interacting with AGE receptors of mesangial cells. In the present study, GAmodified BSA (GA-BSA) and MG-modified BSA (MGBSA) were prepared as model AGE proteins and their plasma and renal clearance examined in mice. The endocytic uptake of these AGE proteins by mesangial cells separated from SR-A knock-out mice was also compared with that of control mice.

\section{Materials and methods}

Chemicals BSA (fraction V) was purchased from Wako Pure Chemical Industries (Osaka, Japan). Penicillin G and streptomycin were purchased from Life Technologies (New York, NY, USA). RPMI 1640 medium, DMEM, Hanks' balanced salt solution (HBSS), biotinamidohexanoic acid $\mathrm{N}$-hydroxysuccinimido ester (BNHS) and collagenase were obtained from Sigma Chemical (St Louis, MO, USA). ITS premix was obtained from Becton Dickinson (Bedford, MA, USA). Indium 111 trichloride $(74 \mathrm{MBq} / \mathrm{ml}$ in $0.02 \mathrm{~mol} / 1$ $\mathrm{HCl}$ ) was a gift from Nihon Medi-Physics (Takarazuka, Japan), and $\mathrm{Na}^{125} \mathrm{I}(3.7 \mathrm{GBq} / \mathrm{ml}$ in $\mathrm{NaOH})$ was purchased from Amersham Pharmacia Biotech (Little Chalfont, Bucks, UK). All reagents used were of the highest grade available from commercial sources.
Animals Male ddY (27-32 g) and C57BL/6 (22-25 g) mice were obtained from SLC (Shizuoka, Japan). The mice were kept under a 12/12 h light/dark cycle in a humidity-controlled room.

Mice lacking both SR-A were established from C57BL/6 by the targeted disruption of exon 4 of the type AI/type AII SR gene, which is essential for the formation of functional trimeric receptors in A3-1 embryonic stem cells. Descriptions of the construct and the phenotypic expression in homozygous knock-out mice have been reported previously [24]. Normal littermates were bred as controls.

Ligand preparation To prepare GA-BSA, $5 \mathrm{mg} / \mathrm{ml}$ BSA was incubated with $50 \mathrm{mmol} / 1$ of GA at $37^{\circ} \mathrm{C}$ for 3 days in PBS, followed by dialysis against PBS [3]. MG-BSA was prepared under identical conditions except that $50 \mathrm{mmol} / \mathrm{l}$ carbonate buffer (pH 9.0) was used instead of PBS. LDL $(d=1.019-1.063 \mathrm{~g} / \mathrm{ml})$ was isolated by the sequential ultracentrifugation of fresh plasma from normolipidaemic subjects after overnight fasting, and dialysed against $0.15 \mathrm{~mol} / \mathrm{l}$ $\mathrm{NaCl}$ per $1 \mathrm{mmol} / \mathrm{l}$ EDTA (pH 7.4) [25]. Acetylated LDL (Ac-LDL) was prepared by the chemical modification of LDL with acetic anhydride as described previously [25]. To prepare oxidized LDL (Ox-LDL), LDL was dialysed against PBS to remove EDTA. LDL $(0.1 \mathrm{mg} / \mathrm{ml})$ was then incubated with a $5 \mu \mathrm{mol} / 1$ solution of $\mathrm{CuSO}_{4}$ at $37^{\circ} \mathrm{C}$ for $24 \mathrm{~h}$, followed by the addition of $1 \mathrm{mmol} / \mathrm{l}$ EDTA and cooling.

Protein labelling with ${ }^{111}$ In and ${ }^{125}$ I BSA, GA-BSA, and MG-BSA were labelled with ${ }^{111}$ In using diethylenetriaminepentaacetic acid (DTPA) as the bifunctional chelating agent as described previously [26]. DTPA was attached to BSA by dissolving the protein $(5 \mathrm{mg})$ in $1.0 \mathrm{ml}$ of $0.1 \mathrm{~mol} / \mathrm{l}$ HEPES buffer $(\mathrm{pH} 7.0)$, and then adding $50 \mu \mathrm{g}$ of DTPA anhydride in $10 \mu \mathrm{l}$ of DMSO. After stirring for $1 \mathrm{~h}$ at room temperature, unreacted DTPA was removed by placing the solution on a Sephadex G-25 column $(1 \times 40 \mathrm{~cm})$ followed by elution with $0.1 \mathrm{~mol} / 1$ sodium acetate buffer (pH 6.0). Fractions containing DTPA-BSA were combined based on the absorption at $280 \mathrm{~nm}$ and concentrated by an ultrafiltration apparatus from Advantec (Dublin, CA, USA). Twenty microlitres of ${ }^{111} \mathrm{InCl}_{3}$ solution, $60 \mu$ of DTPA$\mathrm{BSA}$, and $20 \mu \mathrm{l}$ of $1 \mathrm{~mol} / \mathrm{l}$ sodium acetate buffer ( $\mathrm{pH}$ 6.0) were added. After incubation for $30 \mathrm{~min}$ at room temperature, unreacted ${ }^{111} \mathrm{InCl}_{3}$ was removed by adding the solution to a PD-10 column followed by elution with 0.1 mol/l sodium acetate buffer ( $\mathrm{pH}$ 6.0). The ${ }^{111}$ In-enriched fractions were selected on the basis of their radioactivity and concentrated by ultrafiltration. Radioactivity was determined with a well counter. The specific activities of ${ }^{111} \mathrm{In}$ BSA, ${ }^{111}$ In-GA-BSA, and ${ }^{111}$ In-MG-BSA were $12 \times 10^{6}$, $11 \times 10^{6}$ and $11 \times 10^{6} \mathrm{cpm} / \mathrm{mg}$ protein, respectively.

GA-BSA and MG-BSA were labelled with ${ }^{125}$ I by IodoGen (Pierce). A solution containing $10 \mu \mathrm{l}$ of $\mathrm{Na}^{125}$ I solution and $0.5 \mathrm{mg}$ of BSA in $0.2 \mathrm{ml}$ of $0.1 \mathrm{~mol} / 1$ sodium phosphate buffer ( $\mathrm{pH}$ 7.4) in a Iodo-Gen-adhered test tube was incubated for $30 \mathrm{~min}$ at room temperature. Unreacted $\mathrm{Na}^{125} \mathrm{I}$ was removed by adding the solution to a PD-10 column followed by elution with PBS. The ${ }^{125}$ I-labelled fractions 
were combined on the basis of their radioactivity, as determined with a well counter. The specific activities of GABSA and MG-BSA were 800 and $900 \mathrm{cpm} / \mathrm{ng}$ protein, respectively.

Clearance experiments Prior to intravenous administration, trace amounts of ${ }^{111}$ In-BSA, ${ }^{111}$ In-GA-BSA, or ${ }^{111}$ In-MG-BSA were diluted with saline, and the protein concentration was adjusted to $0.1 \mathrm{mg} / \mathrm{ml}$. Each radiolabeled protein $(0.1 \mathrm{mg} / \mathrm{kg}, 10 \mathrm{kcpm})$ was injected as a bolus into the tail vein of male ddY mice at 7 weeks of age after being anaesthetised with diethylether [27]. After 1,3,5, 10, 15, or $20 \mathrm{~min}$, the animals were killed, and the kidney and the liver were excised, followed by a determination of their radioactivities for kidney and liver clearance. To determine the organ distribution of each ${ }^{111}$ In-labelled protein, the animals were similarly killed at 20 min after injection, and organs such as kidney, liver, pancreas, spleen, lung, heart, and brain were excised to determine their radioactivity. Care and treatment of the animals was in compliance with the "Principles of Laboratory Animal Care" (NIH publication no. 85-23, revised 1985). The protocol was approved by the University of Kumamoto institutional review board for animal procedures.

Data analyses In this study, the radioactivity of liver and kidney samples was used to calculate the apparent uptake clearances of BSA, GA-BSA, and MG-BSA. The radioactivity of all samples and that of the plasma was normalised to the percentage of dose or percentage of dose per millilitre, respectively. Plasma concentrations were analysed by a biexponential function using the non-linear least-squares computer program MULTI [28]. The two-compartment model was chosen according to the Akaike information criterion.

Total body clearance of radioactivity $\left(\mathrm{CL}_{\text {total }}\right)$ was calculated by:

$\mathrm{CL}_{\text {total }}=\frac{D}{\mathrm{AUC}}$

where $D$ is the dose of radioactivity administered, and AUC is the area under the plasma concentration-time curve extrapolated to infinity.

Assuming zero or negligible leakage of radioactivity from organs, the apparent organ uptake clearance $\left(\mathrm{CL}_{\text {organ }}\right)$ may be expressed as:

$$
\mathrm{CL}_{\text {organ }}=\frac{\mathrm{X}_{\mathrm{ti}}}{\mathrm{AUC}_{\mathrm{t} 0-\mathrm{ti}}}
$$

where $X_{\mathrm{ti}}$ is the amount of radioactivity in the organ of interest at the end of the experiment, and AUCt0-ti is the area under the curve for the time interval from $t 0=$ administration of the compound, to $t i=$ end of the experiment.

Preparation of biotinylated antibody against GA-BSA The monoclonal anti-GA-BSA antibody was prepared and pu- rified by protein G-immobilised Sepharose gel chromatography to IgG1, as described previously [5]. This monoclonal antibody was shown to be specific for the glycolaldehydederived pyridine (GA-pyridine) structure [5] and is referred to as the anti-GA-pyridine antibody in the present study [5]. The anti-GA-pyridine antibody $(0.5 \mathrm{mg})$ was biotinylated by reaction with $50 \mu \mathrm{g}$ of BNHS for $1 \mathrm{~h}$ at room temperature in $0.1 \mathrm{~mol} / \mathrm{l}$ carbonate buffer ( $\mathrm{pH} 8.4$ ) and dialysed against PBS to remove unreacted BNHS. The immunoreactivity of the biotinylated antibody for GA-BSA was indistinguishable from the unlabelled anti-GA-pyridine antibody as determined by ELISA.

Immunohistochemistry GA-BSA (5 mg/ $\mathrm{kg}$ ) was injected as a bolus into the tail vein of male C57BL/6 mice at 7 weeks of age after being anaesthetised with diethylether. After $5 \mathrm{~min}$, the animals were killed, and the kidneys removed, fixed with a $2 \%$ periodate/lysine/paraformaldehyde fixative at $4{ }^{\circ} \mathrm{C}$ for $5 \mathrm{~h}$ and washed with PBS containing a graded series of sucrose $(10,15$ and $20 \%)$. After immersion in PBS containing 20\% sucrose to inhibit ice crystal formation, the tissues were embedded in OCT compound (Sakura Fine Technical, Tokyo, Japan), frozen in liquid nitrogen, and stored at $-80^{\circ} \mathrm{C}$ until used. Sections were cut 5- $\mu \mathrm{m}$ thick with a cryostat (HM-500 M; Microm, Walldorf, Germany) and mounted on poly-L-lysine-coated slides.

For immunohistochemical analysis, cryostat sections were prepared and examined by the indirect immunoperoxidase method. Briefly, after inhibition of endogenous peroxidase activity by the method of Isobe et al. [29], the sections were incubated with $10 \mu \mathrm{g} / \mathrm{ml}$ of biotinylated antiGA-pyridine antibody, washed with PBS, and reacted with streptavidin/HRP (DAKO). After visualisation with 3,3'diaminobenzidine (Dojin Chemical, Kumamoto, Japan), the sections were counterstained with haematoxylin (Mutoh Chemical, Tokyo, Japan). For negative controls, the identical procedures were performed, but the antibody and the biotinylated antibody were omitted. Non-immune mouse IgG1 was also used as a negative control, and staining showed no evidence for an immunoreaction. For the immunoabsorption test, $10 \mu \mathrm{g} / \mathrm{ml}$ of biotinylated anti-GApyridine antibody was preincubated with $10 \mu \mathrm{g} / \mathrm{ml}$ of GA-BSA at $37^{\circ} \mathrm{C}$ for $1 \mathrm{~h}$ and allowed to react with streptavidin/HRP.

Cellular experiments with mesangial cells Isolation of glomerular cores was performed by the method of Mori et al. [30] with a minor modification. Briefly, the kidneys of male ddY mice at 7 weeks of age were removed under anaesthesia with diethylether and cut into slices. Each slice was pressed through a $425-\mu \mathrm{m}$-pore-size sieve. The passthrough was rinsed three times in HBSS and pellets were centrifuged at 3,000 rpm for $10 \mathrm{~min}$. The pellets were then incubated for $30 \mathrm{~min}$ at $37^{\circ} \mathrm{C}$ with $750 \mathrm{U} / \mathrm{ml}$ of collagenase in $5 \mathrm{ml}$ of HBSS, followed by washing three times with HBSS for centrifugation and passing through two sieves with pore sizes of 100 and $40 \mu \mathrm{m}$. The glomerular cores remaining on the finest sieve were cultured at $37^{\circ} \mathrm{C}$ for 2 
weeks in RPMI 1640 medium with $20 \%$ FCS, $100 \mathrm{U} / \mathrm{ml}$ penicillin, $10 \mu \mathrm{g} / \mathrm{ml}$ streptomycin, and ITS premix in $75-$ $\mathrm{cm}^{2}$ plastic tissue culture flasks in a $5 \% \mathrm{CO}_{2}$ incubator. Mesangial cells obtained from the fifth to eighth passage were plated on 12 -well plates at $7.5 \times 10^{4}$ cells/well and cultured for $24 \mathrm{~h}$ at $37^{\circ} \mathrm{C}$ in RPMI 1640 medium with $20 \%$ FCS, $100 \mathrm{U} / \mathrm{ml}$ penicillin, and $10 \mu \mathrm{g} / \mathrm{ml}$ streptomycin before each experiment described below. Except for the binding experiments described below, all cellular experiments were performed at $37^{\circ} \mathrm{C}$ in a humidified atmosphere of $5 \%$ $\mathrm{CO}_{2}$ in air.

Cultured mesangial cells used in the present study formed a uniform cell population based on the following criteria: (1) spindle shape; (2) positive immunohistochemistry for both $\beta$-actin (Fig. 1a) and vimentin (Fig. 1b), but negative for cytokeratin (Fig. 1c) and Factor VIII (Fig. 1d); (3) contraction in response to angiotensin II and vasopressin; and (4) induction of TGF- $\beta$ by serotonin [31].

An additional note to the method: although our modified method-sieving of glomerular cores after collagenase treatment-gives a high yield of glomerular cores and subsequent mesangial cells, special attention has to be paid to the possibility that incubation with collagenase could lead to the overdigestion of glomerular cores and a low yield of glomerular core on the finest sieve. To prevent this, the readers are highly recommended to do preliminary experiments to determine the adequate incubation time for collagenase treatment as well as selection of the suitable collagenase batch from commercially available ones.

For binding experiments, confluent mesangial cells were washed twice with $1.0 \mathrm{ml}$ of PBS and incubated for 90 min at $4^{\circ} \mathrm{C}$ with $1.0 \mathrm{ml}$ of DMEM supplemented with $3 \%(\mathrm{w} / \mathrm{v})$ BSA containing the indicated concentrations of ${ }^{125}$ I-GA-BSA or ${ }^{125}$ I-MG-BSA with or without a 50 -fold excess of unlabelled GA-BSA or MG-BSA. After washing three times with ice-cold PBS containing $1 \%(\mathrm{w} / \mathrm{v})$ BSA and twice further with PBS, the cells were dissolved in $1.0 \mathrm{ml}$ of $0.1 \mathrm{~mol} / 1 \mathrm{NaOH}$, and cell-bound radioactivity and cellular proteins were determined.

For uptake and degradation experiments, confluent cells were washed twice with PBS and incubated at $37^{\circ} \mathrm{C}$ with $1.0 \mathrm{ml}$ of DMEM supplemented with $3 \%(\mathrm{w} / \mathrm{v})$ BSA containing the indicated concentrations of ${ }^{125} \mathrm{I}-\mathrm{GA}-\mathrm{BSA}$ or ${ }^{125}$ I-MG-BSA with or without a 50 -fold excess of unlabelled GA-BSA or MG-BSA. After incubation for the indicated time intervals, culture medium $(0.75 \mathrm{ml})$ was taken from each well and mixed with $0.3 \mathrm{ml}$ of $40 \%$ trichloroacetic acid on a vortex mixer. To this solution was
Fig. 1 Immunohistochemical staining for $\beta$-actin (a), vimentin (b), cytokeratin (c) and Factor VIII (d) in mouse mesangial cells. Staining of mouse mesangial cells between the fifth and eighth passages was positive for $\beta$-actin (a) and vimentin (b), but negative for cytokeratin (c) and Factor VIII (d)
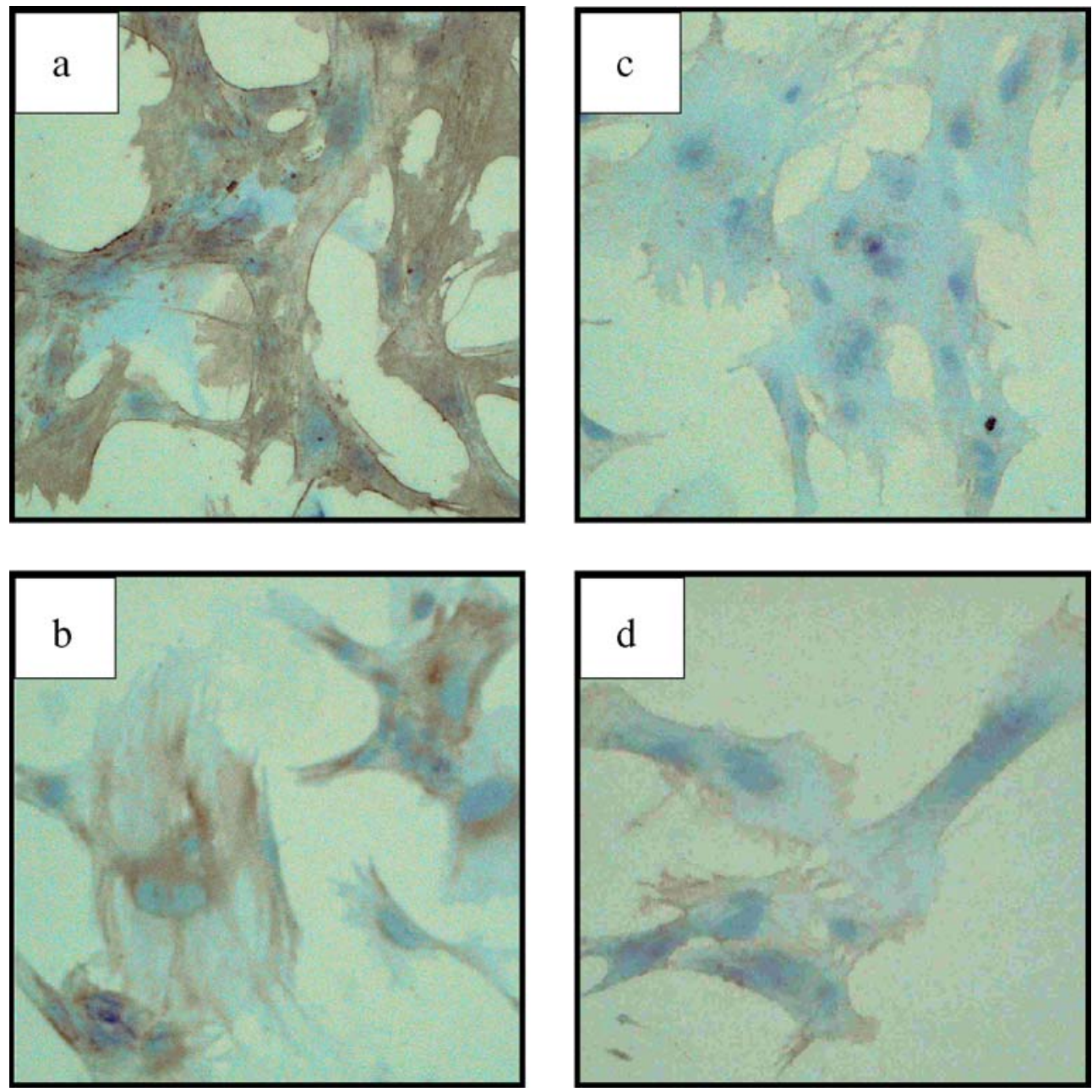
added $0.2 \mathrm{ml}$ of $0.7 \mathrm{~mol} / 1 \mathrm{AgNO}_{3}$, followed by centrifugation. The resulting supernatant was used to determine trichloroacetic acid-soluble radioactivity, which was taken as an index of cellular degradation, since AGE proteins are endocytosed by the cells and delivered to lysosomes where they are degraded and excreted into the culture medium in a trichloroacetic acid-soluble form. The remaining cells in each well were washed three times with $1.0 \mathrm{ml}$ of PBS containing $1 \%(\mathrm{w} / \mathrm{v}) \mathrm{BSA}$ and twice more with PBS. The cells were lysed at $37^{\circ} \mathrm{C}$ for $30 \mathrm{~min}$ with $1.0 \mathrm{ml}$ of $0.1 \mathrm{~mol} / 1$ $\mathrm{NaOH}$. One portion was used to determine the radioactivity of the cell-associated ligand and the other was used to determine cellular proteins using the bicinchoninic acid protein assay reagent (Pierce) [32].

For inhibition assays, mesangial cells were incubated at $4^{\circ} \mathrm{C}$ for $90 \mathrm{~min}$ with $2.5 \mathrm{\mu g} / \mathrm{ml}$ of ${ }^{125}$ I-GA-BSA or ${ }^{125} \mathrm{I}$ MG-BSA in the absence (control) or presence of 40-fold $(100 \mu \mathrm{g} / \mathrm{ml})$ of unlabelled ligands such as GA-BSA, MGBSA, Ox-LDL, Ac-LDL, and LDL. The extents of cellbound ${ }^{125} \mathrm{I}-\mathrm{GA}-\mathrm{BSA}$ and ${ }^{125} \mathrm{I}-\mathrm{MG}$-BSA were determined as described above.

Statistical analysis Data are expressed as mean \pm SD. Differences between groups were evaluated by paired Student's $t$-test. A $p$ value less than 5\% denoted a statistically significant difference.

\section{Results}

Plasma clearance of GA-BSA and MG-BSA Figure 2 shows the plasma clearance in mice that had been intravenously injected with ${ }^{111}$ In-BSA, ${ }^{111}$ In-GA-BSA, and ${ }^{111}$ In-MG-BSA; the clearance rate of ${ }^{111}$ In-BSA was very slow, whereas the radioactivity of ${ }^{111}$ In-GA-BSA or ${ }^{111}$ InMG-BSA was rapidly cleared from the circulation, with about $80 \%$ of the injected ${ }^{111}$ In-GA-BSA or ${ }^{111}$ In-MG-BSA

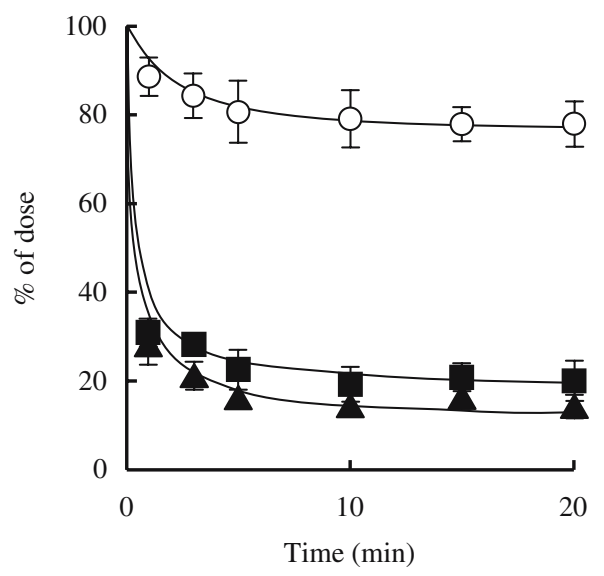

Fig. 2 Plasma clearance of ${ }^{111}$ In-BSA, ${ }^{111}$ In-GA-BSA, and ${ }^{111}$ InMG-BSA after intravenous administration to mice; ${ }^{111}$ In-BSA (open circles), ${ }^{111}$ In-GA-BSA (closed triangles), and ${ }^{111}$ In-MG-BSA (closed squares) were injected as a bolus through the tail vein of mice, and the relative radioactivities are plotted against time after injection. Each data point represents the mean \pm SD for three mice being eliminated within 5 min after intravenous administration. Figure 3 shows tissue distribution of ${ }^{111}$ In-BSA, ${ }^{111}$ In-GA-BSA, and ${ }^{111}$ In-MG-BSA. At 20 min after the injection of ${ }^{111}$ In-GA-BSA, $38 \%$ of the total injected radioactivity accumulated in the liver, and its renal accumulation corresponded to $21 \%$ (Fig. 3b). A similar pattern was obtained for ${ }^{111} \mathrm{In}-\mathrm{MG}-\mathrm{BSA}$, with $32 \%$ for hepatic accumulation and $19 \%$ for renal accumulation (Fig. 3c). Accumulation by other organs such as pancreas, spleen, lung, heart, and brain was negligibly low, and the pattern was indistinguishable from that of BSA (Fig. 3a).

The clearance rates for liver and kidney were also calculated using the nonlinear least-squares computer program MULTI (Table 1). These $\mathrm{CL}_{\text {liver }}$ and $\mathrm{CL}_{\text {kidney }}$ values for GA-BSA and MG-BSA were significantly larger than those for BSA, suggesting the presence of a selective uptake system for GA-BSA and MG-BSA in both the liver and kidney.

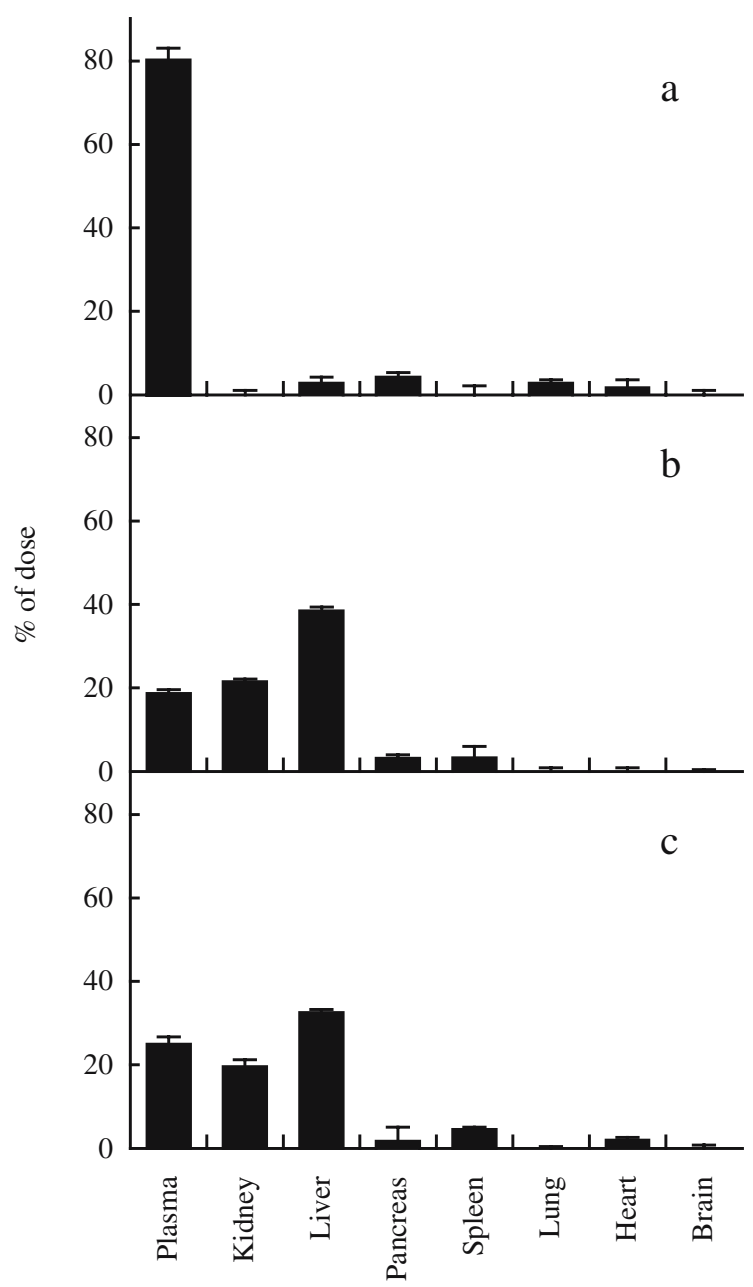

Fig. 3 Anatomical distribution of intravenously injected ${ }^{111}$ In-BSA (a), ${ }^{111}$ In-GA-BSA (b), and ${ }^{111}$ In-MG-BSA (c). The mice used for plasma clearance studies (Fig. 2) were analysed for anatomical distribution of radioactivity $20 \mathrm{~min}$ after the injection. Approximately $90 \%$ of the injected dose was recovered in the tissues listed in all experiments. Results are means \pm SD for three separate experiments 
Table 1 Uptake of ${ }^{111}$ In-BSA, ${ }^{111}$ In-GA-BSA and ${ }^{111}$ In-MG-BSA by mice liver and kidney

\begin{tabular}{lccc}
\hline & \multicolumn{3}{l}{ Clearance $(\mu \mathrm{l} / \mathrm{h})$} \\
\cline { 2 - 4 } & $\mathrm{CL}_{\text {total }}$ & $\mathrm{CL}_{\text {liver }}$ & $\mathrm{CL}_{\text {kidney }}$ \\
\hline BSA & $57.2 \pm 18.1$ & $6.3 \pm 3.2$ & $6.9 \pm 2.7$ \\
GA-BSA & $16,573.8 \pm 1,173.5$ & $9,123.5 \pm 603.2$ & $3,767.2 \pm 481.6$ \\
MG-BSA & $11,615.6 \pm 869.2$ & $5,546.3 \pm 251.3$ & $2,505.3 \pm 338.2$ \\
\hline
\end{tabular}

Values are means \pm SD of three sets of experiments

Immunohistochemical distribution in kidney of intravenously injected GA-BSA To determine the cells responsible for renal clearance of AGE proteins from the circulation, the distribution of intravenously administered GA-BSA in the kidney was examined immunohistochemically using the biotinylated anti-GA-pyridine antibody as described in "Materials and methods." At 5 min after an intravenous injection of GA-BSA, positive immunoreactivities were found in the glomerular area with mesangial cells and endothelial cells being the main cellular components (Fig. 4a). These positive immunoreactions in the glomerulus were completely inhibited when the biotinylated antibody was pretreated with $10 \mu \mathrm{g} / \mathrm{ml}$ of GA-BSA (Fig. 4c).
Furthermore, no positive immunoreactions were found in the renal glomerulus when the mice were subjected to an intravenous injection of BSA (Fig. 4d). It seems likely from these immunohistochemical data that mesangial cells, at least, are responsible for the renal clearance of intravenously administered GA-BSA.

GA-BSA and MG-BSA undergo receptor-mediated endocytosis by mesangial cells To determine the mechanism for the selective accumulation of intravenously injected GABSA and MG-BSA in the mesangium, we examined the cellular interaction of GA-BSA and MG-BSA using isolated mesangial cells. The total binding of ${ }^{125} \mathrm{I}-\mathrm{GA}-\mathrm{BSA}$ to these cells at $4{ }^{\circ} \mathrm{C}$ was inhibited by $>80 \%$ by the presence of an excess amount of unlabelled GA-BSA (Fig. 5a). The specific binding, which was obtained by subtracting nonspecific binding from the total binding, showed a saturation curve for which Scatchard analysis revealed a binding site with an apparent $\mathrm{Kd}$ of $6.93 \mu \mathrm{g} / \mathrm{ml}$ and a maximal binding of $94.11 \mathrm{ng} / \mathrm{mg}$ of cell protein (Fig. 5a, inset). The specific binding of MG-BSA to mesangial cells was also saturable (Fig. 5b), the Scatchard analysis of which gave a binding site with an apparent $\mathrm{Kd}$ of $6.80 \mu \mathrm{g} / \mathrm{ml}$ and a maximal surface binding of $27.69 \mathrm{ng} / \mathrm{mg}$ of cell protein
Fig. 4 Immunohistochemical localisation in kidney of GA-BSA after its intravenous administration to mice. The kidney was removed 5 min after an injection of GA-BSA or BSA in the form of a bolus through the tail veins of mice. a Anti-GApyridine antibody-positive products were observed in mesangial cells and endothelial cells in glomerulus obtained from mice that had been administered GA-BSA (arrows). b Positive reactions for anti-GA-pyridine antibody in glomerular areas observed in (a) were significantly weakened in SR-A knock-out mice. c Such positive reactions disappeared after preincubation of the antibody with $10 \mu \mathrm{g} / \mathrm{ml}$ of GA-BSA. d No immunoreactivity of anti-GApyridine antibody was detected in the glomerulus obtained from mice administered BSA
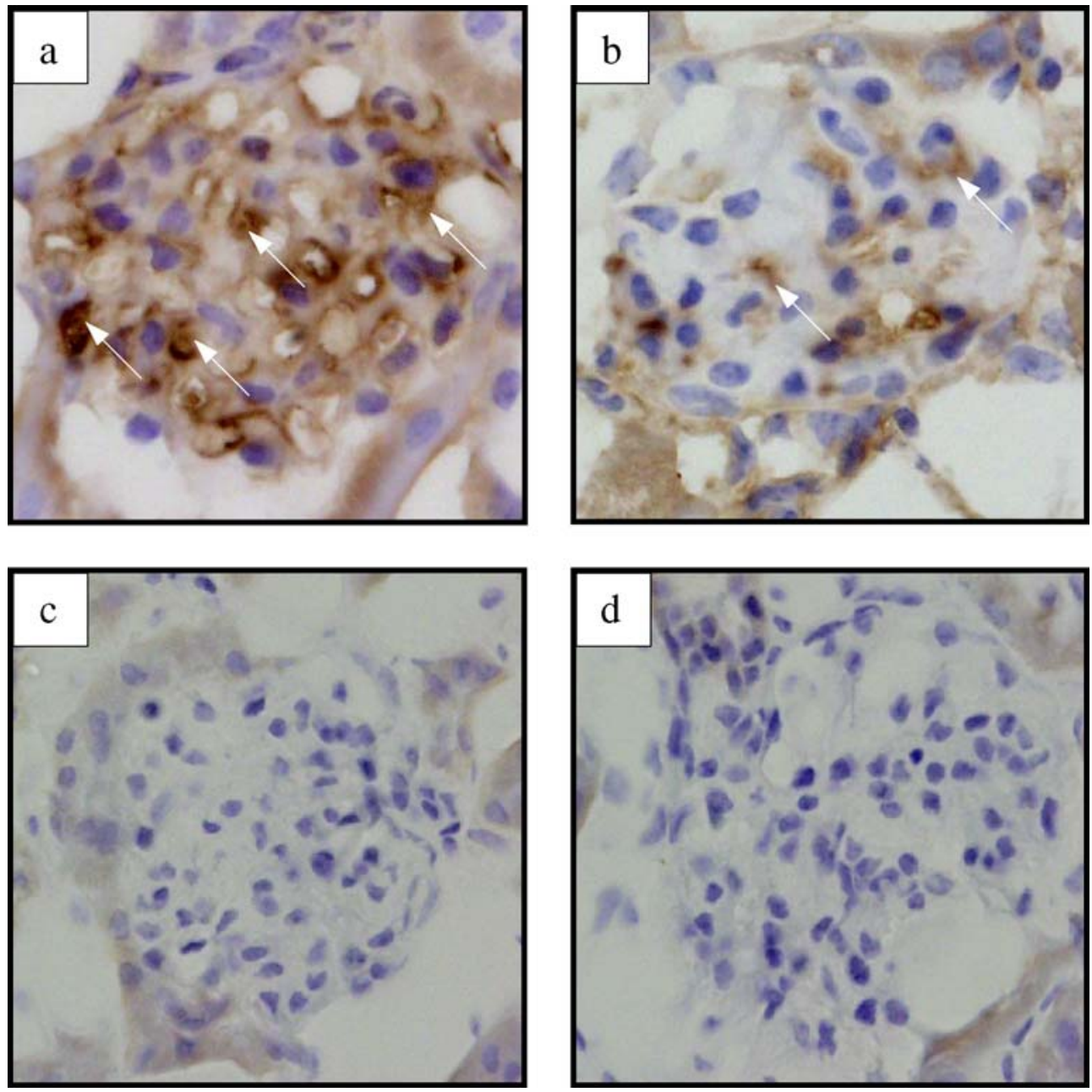


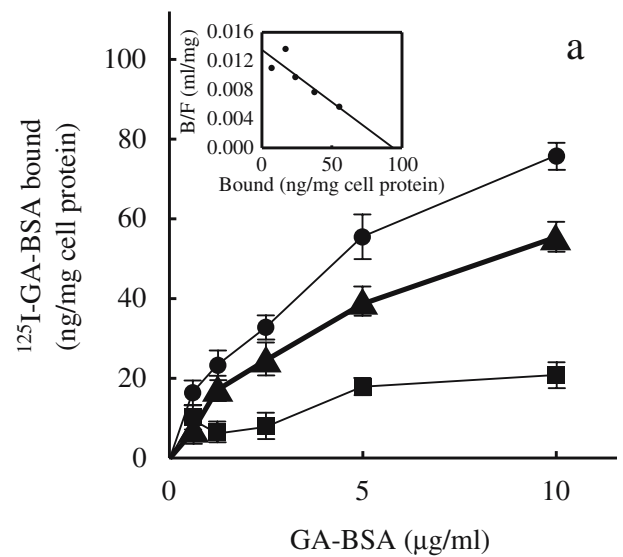

Fig. 5 Binding of ${ }^{125}$ I-GA-BSA (a) and ${ }^{125}$ I-MG-BSA (b) to mouse mesangial cells. Mesangial cells were incubated at $4^{\circ} \mathrm{C}$ for $90 \mathrm{~min}$ with the indicated concentrations of ${ }^{125} \mathrm{I}-\mathrm{GA}-\mathrm{BSA}$ (a) or ${ }^{125} \mathrm{I}-\mathrm{MG}$ BSA (b) in the presence (closed squares) or absence (closed circles)

(Fig. 5b, inset). These results indicate that mesangial cells possess a high-affinity binding site for GA-BSA and MG-BSA.

To determine the post-binding outcome of GA-BSA and MG-BSA, these mesangial cells were incubated with ${ }^{125} \mathrm{I}-$ GA-BSA and ${ }^{125} \mathrm{I}-\mathrm{MG}-\mathrm{BSA}$ at $37^{\circ} \mathrm{C}$. The amount of cellassociated ${ }^{125}$ I-GA-BSA increased with time (Fig. 6a) followed by a parallel increase in the amount of ${ }^{125} \mathrm{I}-\mathrm{GA}$ BSA degraded by these cells (Fig. 6b). In a similar fashion, the amount of ${ }^{125}$ I-MG-BSA associated with (Fig. 6c) and those degraded by these cells (Fig. 6d) increased with time. Based on these experiments, it appears likely that mesangial

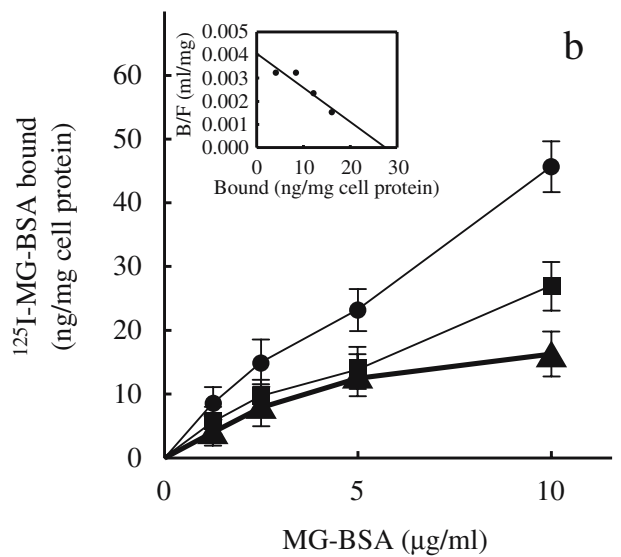

of 50-fold unlabelled ligands. Closed triangles indicate the specific binding of each ligand. Inset Scatchard analysis based on specific binding results for GA-BSA (a) and MG-BSA (b) to mesangial cells. Results are the means $\pm \mathrm{SD}$ of three separate experiments
Fig. 6 Time-dependent endocytic uptake $(\mathbf{a}, \mathbf{c})$ and degradation $(\mathbf{b}, \mathbf{d})$ by mouse mesangial cells of ${ }^{125}$ I-GA-BSA $(\mathbf{a}, \mathbf{b})$ and ${ }_{125}$ I-MG-BSA (c, d). Mesangial cells were incubated at $37^{\circ} \mathrm{C}$ for the indicated times with $5 \mu \mathrm{g} / \mathrm{ml}$ of ${ }^{125}$ I-GA-BSA or ${ }^{125}$ I-MGBSA in the presence (closed squares) or absence (closed circles) of 50-fold unlabelled ligands. Closed triangles indicate the specific association or degradation of each ligand. The amounts of cell-associated ${ }^{125} \mathrm{I}$ GA-BSA and ${ }^{125}$ I-MG-BSA and their degradation were determined as described in Materials and methods. Results are the means \pm SD of three separate experiments
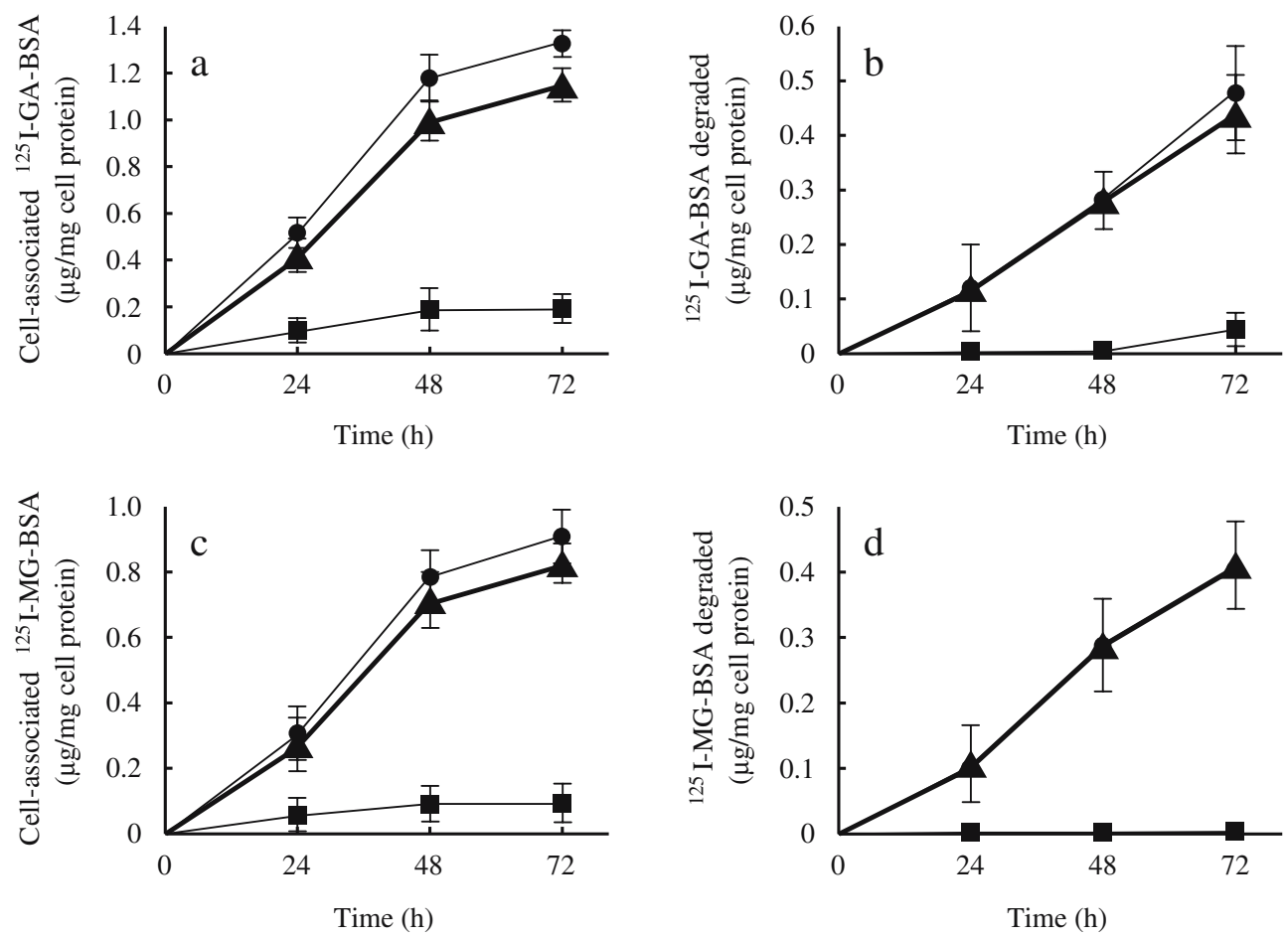


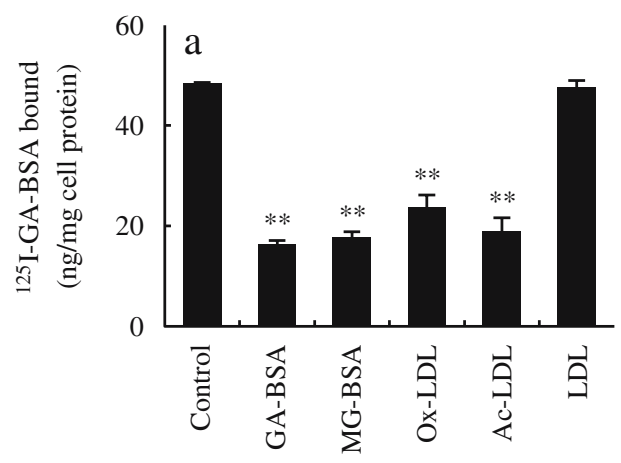

Fig. 7 Effects of several ligands on binding to mouse mesangial cells of ${ }^{125} \mathrm{I}-\mathrm{GA}-\mathrm{BSA}$ (a) and ${ }^{125} \mathrm{I}-\mathrm{MG}-\mathrm{BSA}$ (b). Mesangial cells were incubated at $4{ }^{\circ} \mathrm{C}$ for $90 \mathrm{~min}$ with $2.5 \mu \mathrm{g} / \mathrm{ml}$ of ${ }^{125} \mathrm{I}-\mathrm{GA}-\mathrm{BSA}$ or ${ }^{125} \mathrm{I}-\mathrm{MG}-\mathrm{BSA}$ in the absence (control) or the 40-fold presence of unlabelled ligands such as GA-BSA, MG-BSA, Ox-LDL, Ac-LDL,

that GA-BSA and MG-BSA are recognised by mesangial cells via a scavenger receptor(s) and undergo receptormediated endocytosis.

Endocytic uptake of GA-BSA by mesangial cells from SR-A knock-out mice Among the scavenger receptors, SR-A [17], CD36 [18], SR-BI [19], and LOX-1 [20] have been identified as the AGE receptors. In this study we determined the extent of contribution of SR-A to the endocytic degradation of GA-BSA by mesangial cells. The specific binding of ${ }^{125}$ I-GA-BSA to mesangial cells from SR-A knock-out mice was reduced by $37 \%$, compared with that of wild-type mesangial cells. The extent of subsequent endocytic degradation of ${ }^{125}$ I-GA-BSA by mesangial cells from SR-A knock-out mice was reduced by more than $80 \%$, compared with those of wild-type cells (Fig. 8). These results suggest that SR-A probably plays a major

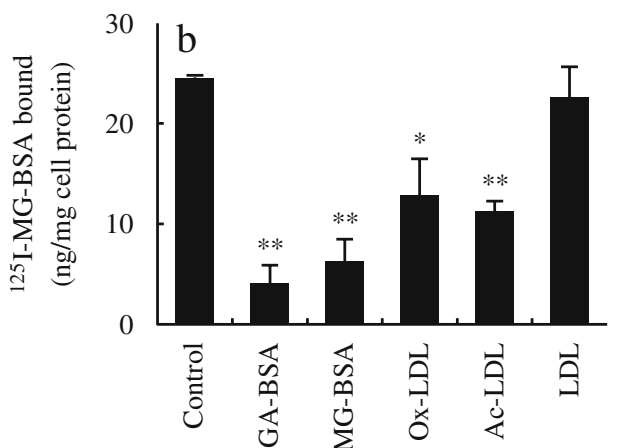

and LDL. The extent of cellular binding of ${ }^{125} \mathrm{I}-\mathrm{GA}-\mathrm{BSA}$ and ${ }^{125} \mathrm{I}$ MG-BSA was determined as described in Materials and methods. Results are the means \pm SD of three separate experiments; ${ }^{*} p<0.05$, $*_{*} p<0.01$, compared with the control

role in the endocytic degradation of GA-BSA by mesangial cells.

To elucidate whether the renal uptake of circulating AGE proteins is mediated through the SR-A pathway in vivo, immunohistochemical experiments with kidneys after the injection of GA-BSA to SR-A knock-out mice were undertaken. Positive reactions were observed in mesangial cells and endothelial cells in wild-type mice (Fig. 4a), but the same reactions in SR-A knock-out mice were less (Fig. 4b), suggesting the glomerular accumulation of GA-BSA from the circulation via SR-A in vivo.

\section{Discussion}

The findings herein show that GA-BSA and MG-BSA leave the circulation rapidly and accumulate in the liver
Fig. 8 Binding to, and endocytic degradation by, mesangial cells from SR-A knock-out mice of ${ }^{125}$ I-GA-BSA. Mesangial cells obtained from SR-A knock-out mice (right; SR-A ${ }^{-/}$) and their littermates (left; SR$\mathrm{A}^{+/+}$) were incubated at $4{ }^{\circ} \mathrm{C}$ for $90 \mathrm{~min}$ (upper panels) or $37^{\circ} \mathrm{C}$ for $72 \mathrm{~h}$ (lower panels) with the indicated concentrations of ${ }^{125}$ I-GA-BSA in the presence (closed squares) or absence (closed circles) of 50fold unlabelled ligands. Closed triangles indicate the specific binding or degradation of ${ }^{125} \mathrm{I}$ GA-BSA. Results are the means \pm SD of three separate experiments; ${ }^{*} p<0.05, * * p<0.01$, compared with the corresponding concentration for the specific binding and endocytic degradation of SR-A ${ }^{+/}$
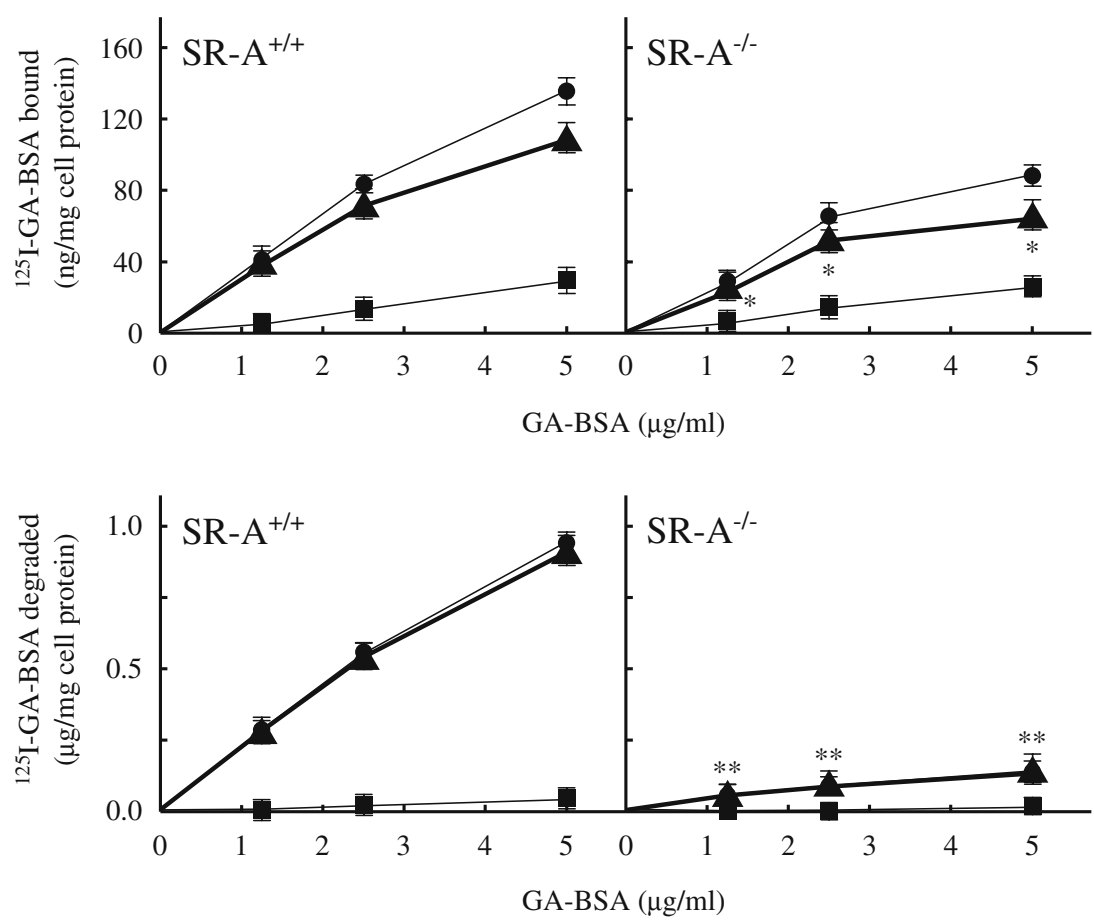
and kidney (Fig. 3). Schmidt et al. [33] prepared AGEBSA by incubating BSA with $250 \mathrm{mmol} / 1$ glucose-6phosphate at $37^{\circ} \mathrm{C}$ for 4 weeks and reported that its plasma clearance in mice was rapid with $70 \%$ of the injected dose being removed from the circulation within $5 \mathrm{~min}$. The amount of organ distribution at $10 \mathrm{~min}$ after intravenous injection was $43 \%$ for the liver, $17 \%$ for the lung, and $7 \%$ for the kidney, suggesting that the liver was the main organ for plasma clearance, but the removal by lungs and kidneys was not negligible. Vlassara et al. [34] prepared AGE rat serum albumin (RSA) by incubating RSA with 50 $\mathrm{mmol} / \mathrm{l}$ glucose-6-phosphate at $37^{\circ} \mathrm{C}$ for 6 weeks, and its daily intravenous injection for 5 months $(25 \mathrm{mg} / \mathrm{kg}$ per day) resulted in the induction of glomerular hypertrophy under which renal AGE accumulation was 1.5-fold higher than the controls, suggesting that intravenously administered AGE proteins could be trapped by the kidney in vivo. The results of the present study consistently showed that intravenously injected ${ }^{111}$ In-labelled GA-BSA or MGBSA in mice led to a significant renal accumulation of these ligands: $21 \%$ for GA-BSA and $19 \%$ for MG-BSA at $20 \mathrm{~min}$ after injection. However, data reported by Smedsrød et al. [35] are somewhat different: AGE-BSA prepared by incubating BSA with $1.7 \mathrm{~mol} / 1$ of glucose for 40 weeks at $37^{\circ} \mathrm{C}$ was labelled with ${ }^{125} \mathrm{I}$ and its hepatic and renal accumulation determined after intravenous injection; the hepatic accumulation was dominant (94\%) whereas the renal accumulation of ligands was very low (2.4\% of the total injected radioactivity) at $60 \mathrm{~min}$ after an intravenous administration in the rat. It is not clear why the extent of renal accumulation after an intravenous injection of these AGE ligands differs from one experiment to another. It could reflect a difference in conditions used in preparing AGE proteins. Alternatively, the difference could be due to the method used for protein labelling. The present study used ${ }^{111}$ In-labelled ligands whereas previous studies had used ${ }^{125}$ I-labelled ligands. Proteins labelled with ${ }^{111}$ In are known to have several advantages over those labelled with ${ }^{125} \mathrm{I}$. The exchange of ${ }^{111}$ In from ${ }^{111}$ In-labelled proteins to other proteins in the lysosome results in a better target retention of radioactivity, whereas an ${ }^{125}$ I-labelled protein can be degraded in lysosomes and released outside the cells, and the resulting amount of ${ }^{125} \mathrm{I}$ radioactivity accumulated in tissues could be underestimated [27].

For the accumulation of intravenously injected GABSA in the kidney, an immunoreaction for the anti-GApyridine antibody was found in the mesangial and endothelial cell areas (Fig. 4a). In this context, previous immunohistochemical studies using anti-AGE antibodies (mainly anti-CML antibodies) revealed the accumulation of AGE proteins in the mesangial lesions in diabetic nephropathy $[8,9]$. In addition, an immunohistochemical study demonstrated the presence of SR-A on mesangial cell membranes in renal biopsy specimens from patients with glomerular diseases [21]. RT-PCR analyses revealed the expression of AGE receptors including OST-48, $80 \mathrm{~K}$ $\mathrm{H}$, and galectin-3 complex in mesangial cells that had been isolated from both normal and diabetic mice, and binding experiments using AGE-BSA with these cells revealed a specific binding with an apparent $\mathrm{Kd}$ of $160-300 \mathrm{nmol} / \mathrm{l}$ [22]. Binding experiments using AGE-BSA with membrane fractions isolated from rat and human mesangial cells revealed a saturable binding with a $\mathrm{Kd}$ of $500 \mathrm{nmol} / \mathrm{l}$ [36]. Finally, from the present study, it is clear that mouse mesangial cells are able to efficiently endocytose and degrade GA-BSA and MG-BSA (Figs. 5 and 6). Collectively, these data indicate that it is likely that mesangial cells are responsible for the renal uptake of AGE proteins from the circulation.

The present result shows that GA-BSA and MG-BSA bind to mouse mesangial cells, and that this binding is effectively inhibited by Ox-LDL and Ac-LDL as well as by MG-BSA, but not by LDL (Fig. 7). This indicates that the ligand specificity of the receptor involved is similar to that of scavenger receptors rather than that of RAGE, OST-48, $80 \mathrm{~K}-\mathrm{H}$, and galectin-3 complex. Consistent with this observation, a previous study showed that ${ }^{125} \mathrm{I}-\mathrm{Ox}$ LDL was degraded by rat mesangial cells, and that this process was effectively inhibited by unlabelled Ac-LDL, suggesting the involvement of scavenger receptor(s) [37]. Four scavenger receptors have been identified as AGE receptors: SR-A [17], CD36 [18], SR-BI [19], and LOX-1 [20]. Since a previous immunohistochemical study using an anti-SR-A antibody showed the presence of SR-A in human mesangial cells [21], and we also confirmed the expression of SR-A mRNA in mouse mesangial cells (data not shown), the contribution of SR-A to the endocytic uptake of these AGE proteins by mesangial cells was assessed in the present study. Our experiments with mesangial cells from SR-A knock-out mice indicate that SR-A contributes $\sim 40 \%$ to the binding and $\sim 80 \%$ to the subsequent degradation of AGE-modified proteins. The difference in contribution of SR-A to binding and degradation is not clear at present, but might be explained by (1) the expression of other AGE receptors such as RAGE, OST-48, $80 \mathrm{~K}-\mathrm{H}$, and galectin-3 complex in mesangial cells [22, 23] and (2) the fact that these receptors do not belong to the endocytosis-coupled receptor (ligand binding to these receptor does not follow the subsequent endocytic uptake, in sharp contrast to SR-A).

A recent study using SR-A knock-out mice has clarified the crucial role of SR-A in the pathogenesis of diabetic nephropathy; diabetic wild-type mice showed typical signs of diabetic nephropathy such as an increase in urinary albumin excretion, glomerular hypertrophy, an increase in mesangial matrix and fibrosis in interstitial tissues, whereas these pathologies were effectively ameliorated in diabetic SR-A knock-out mice (Shikata et al., personal communication).

In summary, the earliest morphological abnormalities in diabetic nephropathy are the thickening of the glomerular basement membrane and the expansion of mesangial lesions due to the accumulation of extracellular matrix [38]. The interaction of AGE-modified proteins with mesangial cells led to an increased production of collagen, fibronectin, laminin, and proteoglycan $[12,13]$. Therefore, the present study provides new evidence indicating that circulating AGE-modified proteins are cleared from the kidney by SR- 
A-mediated endocytic uptake by mesangial cells, suggesting that AGE proteins delivered by this pathway might play some role in the pathogenesis of diabetic nephropathy.

Acknowledgements This work was supported, in part, by grantsin-aid for scientific research from the Ministry of Education, Science, Sports and Culture of Japan (11694298; 11794016).

\section{References}

1. Maillard LC (1912) Action des acids amines sur les sucres: formation des melanoidines par voie methodique. C R Acad Sci (Paris) 154:66-68

2. Horiuchi S, Higashi T, Ikeda K et al (1996) Advanced glycation end products and their recognition by macrophage and macrophage-derived cells. Diabetes 45:73-76

3. Nagai R, Matsumoto K, Ling X, Suzuki H, Araki T, Horiuchi S (2000) Glycolaldehyde, a reactive intermediate for advanced glycation end products, plays an important role in the generation of an active ligand for the macrophage scavenger receptor. Diabetes 49:1714-1723

4. Wells-Knecht KJ, Zyzak DV, Litchfield JE, Thorpe SR, Baynes JW (1995) Mechanism of autoxidative glycosylation: identification of glyoxal and arabinose as intermediates in the autoxidative modification of proteins by glucose. Biochemistry 34 : 3702-3709

5. Nagai R, Hayashi CM, Xia L, Takeya M, Horiuchi S (2002) Identification in human atherosclerotic lesions of GA-pyridine, a novel structure derived from glycolaldehyde-modified proteins. J Biol Chem 277:48905-48912

6. Beisswenger PJ, Howell SK, Touchette AD, Lal S, Szwergold BS (1999) Metformin reduces systemic methylglyoxal levels in type 2 diabetes. Diabetes 48:198-202

7. Takeuchi M, Makita Z, Bucala R, Suzuki T, Koike T, Kameda Y (2000) Immunological evidence that non-carboxymethyllysine advanced glycation end-products are produced from short chain sugars and dicarbonyl compounds in vivo. Mol Med 6: 114-125

8. Tanji N, Markowitz GS, Fu C et al (2000) Expression of advanced glycation end products and their cellular receptor RAGE in diabetic nephropathy and nondiabetic renal disease. J Am Soc Nephrol 11:1656-1666

9. Sugiyama S, Miyata T, Horie K et al (1996) Advanced glycation end-products in diabetic nephropathy. Nephrol Dial Transplant 11:91-94

10. Lal MA, Brismar H, Eklof AC, Aperia A (2002) Role of oxidative stress in advanced glycation end product-induced mesangial cell activation. Kidney Int 61:2006-2014

11. Doi T, Vlassara H, Kirstein M, Yamada Y, Striker GE, Striker LJ (1992) Receptor-specific increase in extracellular matrix production in mouse mesangial cells by advanced glycosylation end products is mediated via platelet-derived growth factor. Proc Natl Acad Sci U S A 89:2873-2877

12. Pugliese G, Pricci F, Romeo G et al (1997) Upregulation of mesangial growth factor and extracellular matrix synthesis by advanced glycation end products via a receptor-mediated mechanism. Diabetes 46:1881-1887

13. Kim YS, Kim BC, Song CY, Hong HK, Moon KC, Lee HS (2001) Advanced glycosylation end products stimulate collagen mRNA synthesis in mesangial cells mediated by protein kinase $\mathrm{C}$ and transforming growth factor- $\beta$. J Lab Clin Med 138:5968

14. Yamagishi S, Inagaki Y, Okamoto T et al (2002) Advanced glycation end product-induced apoptosis and overexpression of vascular endothelial growth factor and monocyte chemoattractant protein-1 in human-cultured mesangial cells. J Biol Chem 277:20309-20315
15. Neeper M, Schmidt AM, Brett J et al (1992) Cloning and expression of a cell surface receptor for advanced glycosylation end products of proteins. J Biol Chem 267:14998-15004

16. Li YM, Mitsuhashi T, Wojciechowicz D et al (1996) Molecular identity and cellular distribution of advanced glycation endproduct receptors: relationship of p60 to OST-48 and p90 to 80K-H membrane proteins. Proc Natl Acad Sci U S A 93: 11047-11052

17. Kodama T, Freeman M, Rohrer L, Zabrecky J, Matsudaira P, Krieger M (1990) Type I macrophage scavenger receptor contains alpha-helical and collagen-like coiled coils. Nature 343: 531-535

18. Ohgami N, Nagai R, Ikemoto M et al (2001) CD36, a member of the class B scavenger receptor family, as a receptor for advanced glycation end products. J Biol Chem 276:3195-3202

19. Ohgami N, Nagai R, Miyazaki A et al (2001) Scavenger receptor class B type I-mediated reverse cholesterol transport is inhibited by advanced glycation end products. J Biol Chem 276:13348-13355

20. Jono T, Miyazaki A, Nagai R, Sawamura T, Kitamura T, Horiuchi S (2002) Lectin-like oxidized low density lipoprotein receptor-1 (LOX-1) serves as an endothelial receptor for advanced glycation end products (AGE). FEBS Lett 511:170-174

21. Takemura T, Yoshioka K, Aya N et al (1993) Apolipoproteins and lipoprotein receptors in glomeruli in human kidney diseases. Kidney Int 43:918-927

22. He CJ, Zheng F, Stitt A, Striker L, Hattori M, Vlassara H (2000) Differential expression of renal AGE-receptor genes in NOD mice: possible role in nonobese diabetic renal disease. Kidney Int 58:1931-1940

23. Schmidt AM, Hori O, Brett J, Yan SD, Wautier JL, Stern D (1994) Cellular receptors for advanced glycation end products: Implications for induction of oxidant stress and cellular dysfunction in the pathogenesis of vascular lesions. Arterioscler Thromb 14:1521-1528

24. Suzuki H, Kurihara Y, Takeya M et al (1997) A role for macrophage scavenger receptors in atherosclerosis and susceptibility to infection. Nature 386:292-296

25. Sakai M, Miyazaki A, Hakamata H et al (1994) Lysophosphatidylcholine plays an essential role in the mitogenic effect of oxidized low density lipoprotein on murine macrophages. J Biol Chem 269:31430-31435

26. Hnatowich DJ, Layne WW, Childs RL (1982) The preparation and labeling of DTPA-coupled albumin. Int J Appl Radiat Isot 33:327-332

27. Staud F, Nishikawa M, Morimoto K, Takakura Y, Hashida M (1999) Disposition of radioactivity after injection of livertargeted proteins labeled with ${ }^{111}$ In or ${ }^{125} \mathrm{I}$ : effect of labeling on distribution and excretion of radioactivity in rats. J Pharm Sci 88:577-585

28. Yamaoka K, Tanigawara Y, Nakagawa T, Uno T (1981) A pharmacokinetic analysis program (multi) for microcomputer. J Pharmacobiodyn 4:879-885

29. Isobe Y, Nakane PK, Brown WR (1977) Studies on translocation of immunoglobulins across intestinal epithelium, I: improvements in the peroxidase-labeled antibody method for application to study of human intestinal mucosa. Acta Histochem Cytochem 10:161-171

30. Mori T, Bartocci A, Satriano J et al (1990) Mouse mesangial cells produce colony-stimulating factor-1 (CSF-1) and express the CSF-1 receptor. J Immunol 144:4697-4702

31. Kasho M, Sakai M, Sasahara T et al (1998) Serotonin enhances the production of type IV collagen by human mesangial cells. Kidney Int 54:1083-1092

32. Matsumoto K, Sano H, Nagai R et al (2000) Endocytic uptake of advanced glycation end products by mouse liver sinusoidal endothelial cells is mediated by a scavenger receptor distinct from the macrophage scavenger receptor class A. Biochem J $352: 233-240$ 
33. Schmidt AM, Hasu M, Popov D et al (1994) Receptor for advanced glycation end products (AGEs) has a central role in vessel wall interactions and gene activation in response to circulating AGE proteins. Proc Natl Acad Sci U S A 91:88078811

34. Vlassara H, Striker LJ, Teichberg S, Fuh H, Li YM, Steffes M (1994) Advanced glycation end products induce glomerular sclerosis and albuminuria in normal rats. Proc Natl Acad Sci U S A 91:11704-11708

35. Smedsrød B, Melkko J, Araki N, Sano H, Horiuchi S (1997) Advanced glycation end products are eliminated by scavengerreceptor-mediated endocytosis in hepatic sinusoidal Kupffer and endothelial cells. Biochem J 322:567-573
36. Skolnik EY, Yang Z, Makita Z, Radoff S, Kirstein M, Vlassara $H$ (1991) Human and rat mesangial cell receptors for glucosemodified proteins: potential role in kidney tissue remodelling and diabetic nephropathy. J Exp Med 174:931-939

37. Jenkins AJ, Velarde V, Klein RL et al (2000) Native and modified LDL activate extracellular signal-regulated kinases in mesangial cells. Diabetes 49:2160-2169

38. Adler S (1994) Structure-function relationships associated with extracellular matrix alterations in diabetic glomerulopathy. J Am Soc Nephrol 5:1165-1172 